\title{
Settlement Intentions of Recently Arrived Immigrants and Refugees in the Netherlands
}

\author{
De Vroome, T., Van Tubergen, F.
}

NOTE: post-print version, May 23, 2013

(post-refereeing, for information see:

http://www.sherpa.ac.uk/romeo/issn/1556-2948/)

This article may not exactly replicate the final version published in the journal. It is not the copy of record.

This research was supported by a grant from Instituut Gak.

The definitive version is available online:

De Vroome, T., Van Tubergen, F. (2014).

Settlement Intentions of Recently Arrived

Immigrants and Refugees in the Netherlands.

Journal of Immigrant and Refugee Studies, 12(1), 47-66.

http://dx.doi.org/10.1080/15562948.2013.810798 


\section{Settlement Intentions of Recently Arrived}

\section{Immigrants and Refugees in the Netherlands}

This study investigates settlement intentions of immigrants and refugees. We combine data from several large-scale surveys collected between 1998 and 2009 in the Netherlands, focusing on the population that reside in the Netherlands ten years or less $(N=4,151)$. Results show that Surinamese and Antillean immigrants and Somalian refugees are generally less likely than other groups to intend to stay permanently in the Netherlands. Moreover, results show individual differences in settlement intentions. Specifically, ties to Dutch majority members and cultural integration are important factors that are positively related to settlement intentions, while such intentions are not significantly related to economic integration.

KEYWORDS settlement intentions, return migration, economic integration, sociocultural integration, refugees, immigrants, Netherlands 


\section{INTRODUCTION}

Large-scale migration towards Western countries has sparked a considerable interest in the settlement patterns of immigrants in the scientific literature. The bulk of the literature focuses on one direction in the settlement patterns of migrants, namely the initial migration to Western host countries. In European countries like the Netherlands or Denmark, however, it turns out that as much as 20 to 50 per cent of immigrants at some point return to the origin country (Bijwaard, 2010; Jensen \& Pedersen, 2007).

Much research on immigrants' settlement and remigration has focused on whether immigrants actually decide to return to the origin country or stay permanently in the host country. Because the longitudinal survey data needed for such analyses is difficult to obtain, information on the stayers and return migrants is often limited to basic demographic characteristics (Alberts \& Hazen, 2005). Analyses of settlement intentions provide a valuable

addition to research on actual settlement behavior, because it opens up the possibility to investigate the characteristics and motivations of potential stayers and returnees in more detail (Alberts \& Hazen, 2005).

The most prominent explanations of immigrants' settlement intentions and behavior are based on economic incentives in the host and origin country, building on human capital theory (Jensen \& Pedersen, 2007). Recent empirical studies in Western European host countries such as Denmark, the Netherlands and the United Kingdom, among immigrants from a variety of source countries, show mixed results however, which suggests that economic integration of immigrants in the host society is not always negatively related to return intentions and return migration (Bijwaard, 2010; Dustmann \& Weiss, 2007; Jensen \& Pedersen, 2007).

This study contributes to the current literature in two ways. First, next to economic incentives we consider socio-cultural conditions that might promote or hinder settlement 
intentions. Recently, researchers have argued that social networks and cultural integration are of crucial importance to migrants' settlement decisions (Alberts \& Hazen, 2005; De Haas \& Fokkema, 2011; Güngör \& Tansel, 2013; Harvey, 2009). Because these prior studies have mainly focused on specific sub-populations of foreign students and highly skilled migrants, more research is needed on how social-cultural integration affects immigrants' settlement intentions.

Second, we elaborate on prior research by studying refugees. Despite the growing research literature on immigrants' settlement intentions and return migration, little is known about the settlement intentions of refugees. Refugees have become a large and distinct group of immigrants in many Western countries, however, and because of their different conditions in the origin country and migration motives their settlement intentions might differ from those of immigrants. In this respect, the Netherlands is an interesting case to study, because it hosts both refugees and immigrants.

We have two main questions in this study. First, how do immigrants and refugees differ in their settlement intentions? Second, to what extent are settlement intentions affected by economic conditions and socio-cultural conditions? To answer these questions, we use survey data on various immigrant and refugee groups in the Netherlands, collected between 1998 and 2009. Because we combine several large scale surveys, we can focus on the settlement intentions of immigrants and refugees who recently arrived in the host country. It is important to focus on the population that recently arrived, because older populations are a selective group of immigrants and refugees that stayed in the host country.

\section{ORIGIN COUNTRIES AND POLITICAL CONDITIONS}

The largest groups of non-Western immigrants in the Netherlands are originally from Turkey, Morocco, Surinam or the Dutch Antilles (Nicolaas, Wobma, \& Ooijevaar, 2010). In the 
1960s, the Netherlands was one of the European countries that recruited labor migrants from Morocco and Turkey. From the 1970s onwards, family reunification and formation led to a further increase in the Turkish and Moroccan immigrant population in the Netherlands (Nicolaas et al., 2010). Currently around 750,000 people of Turkish or Moroccan origin live in the Netherlands, which is around 4.5 per cent of the population.

The early immigration from the former colony of Surinam to the Netherlands mainly consisted of students who came for educational reasons. Following the independence of Surinam in 1975, immigrants from diverse socio-economic backgrounds came to the Netherlands. Like the Surinamese, the immigration of people from the (former) Dutch Antilles concerned people with diverse socio-economic backgrounds, including students but also many underprivileged youth (labor migrants) (Nicolaas et al., 2010). Around 490,000 people with a Surinamese or Antillean background live in the Netherlands which is around 2.9 per cent of the population.

Refugees are distinguished from the other immigrant groups in our study on the basis of their (self-reported) political motives for migration to the Netherlands - as opposed to the labor, family and study motives that are reported by immigrants. The refugees in our study come from Somalia, Iraq, Iran, Afghanistan, and the former Yugoslavia. In each of these countries, intense political problems have resulted in large-scale forced migration in the 1990s and early 2000s (UNHCR, 2007). Because of civil wars in the former Yugoslavia and Somalia, wars in Iraq and Afghanistan, and political suppression in Iran, refugees from these countries now form important minority populations in the Netherlands and other European countries (Nicolaas, Wobma \& Ooijevaar, 2010; UNHCR, 2007). 


\section{ECONOMIC CONDITIONS}

The dominant approach to explanations of immigrants' settlement intentions revolves around economic incentives, based on the economic opportunities in the origin country and the economic opportunities in the host country (Constant \& Massey, 2003; Dustmann \& Weiss, 2007; Jensen \& Pedersen, 2007). Theoretically, the arguments on immigrants' economic incentives build on human capital theory (Constant \& Massey, 2003; Jensen \& Pedersen, 2007). According to human capital theory, migrants try to maximize the returns to their individual skills by moving from one country to another, taking migration costs into account (Constant \& Massey, 2003; Jensen \& Pedersen, 2007).

Subsequently, economic integration of immigrants and refugees in the host country can be an important individual-level motivation to stay in the host country (Jensen \& Pedersen, 2007). What matters is the extent, to which individuals benefit from the host countries' economic opportunities. The more economically successful they are, the more they are expected to settle permanently in the host country (Jensen \& Pedersen, 2007).

\section{SOCIO-CULTURAL CONDITIONS}

In contrast to economic migration theories, researchers have argued that social networks play a role in migration decisions (Boyd, 1989; De Haas \& Fokkema, 2011; Güngör \& Tansel, 2013; MacDonald \& MacDonald, 1964). Immigrants' settlement intentions are influenced by the spatial proximity to relatives and friends, which determines the social incentives involved in migration decisions (Boyd, 1989; Constant \& Massey, 2003; Haug, 2008). Immigrants take into account the social costs of leaving behind family and friends, and the social rewards of reuniting with family and other contacts overseas.

At least three types of social contact should thus be considered, namely contact with natives, contact with co-ethnics in the host country, and contact with people in the country of 
origin. Following the logic of 'location-specific social capital', social ties with people in the origin country are incentives for return migration, because they facilitate re-integration in the origin country (Haug, 2008). On the other hand, both social ties with co-ethnics in the host country and social ties with natives represent social capital at the place of residence, and should therefore be positively associated with the intention to stay in the host country (Haug, 2008). However, it can also be argued that interaction with co-ethnics in the host country can stimulate return migration, because co-ethnic contacts can be a link in transnational social networks that facilitate return migration (Güngör \& Tansel, 2008). In other words, while contact with natives clearly raises the benefits of settlement in the host country, contact with co-ethnics in the host country can have contrasting effects. Therefore, immigrants who have relatively more contact with natives will more likely have the intention to stay in the host country, compared to immigrants who have relatively more contact with co-ethnics.

In addition to economic and social integration in the host society, cultural integration can affect immigrants' return migration decisions. Cultural dissimilarity between the origin and host country is generally considered to be a motivation for leaving the host country (Alberts \& Hazen, 2005; Harvey, 2009). The Netherlands is a country where cultural values such as gender equality and individual autonomy are widespread and form a dominant cultural norm. Therefore, the extent to which individuals do or do not agree with the dominant cultural values in the host society can make them feel either more out of place in the host society or more reluctant to leave the host society and go back to the origin country (Alberts \& Hazen, 2005; Harvey, 2009).

\section{Group-level Differences}

In the period between 1990 and 2010, the levels of economic development, political rights and civil liberties have continued to be generally much more limited in the origin countries of 
refugees than in the origin countries of immigrants in our study. Though the former Yugoslavia has seen relative political stability and liberty in recent years, the political conditions have improved little in Iraq, Iran, Afghanistan and Somalia (Freedomhouse, 2009; UNDP, 2009). From the perspective of refugees, therefore, unstable political circumstances and fear of safety in the origin country can clearly have continued to be a discouragement for returning to the origin country (Leerkes, Galloway \& Kromhout, 2011). Because the economic situation and political circumstances are generally less favorable in the origin countries of refugees, and many refugees will indeed continue to fear for their safety in the country of origin, they will be least likely to intend to return to the origin country. Therefore, we hypothesize that refugees are more likely to intend to settle permanently in the Netherlands than immigrants (H1).

\section{Individual-level Differences}

In addition to characteristics of the origin groups, immigrants' settlement intentions may be related to individual characteristics. Secondly, therefore, we formulate hypotheses at the individual level. Following the neoclassical economic approach, we investigate the presumed positive relation between economic success and the intention to stay in the host country. As indicators of economic success in the host country, we look at employment, occupational status, and perceived financial security. We hypothesize that employment, occupational status and financial security in the Netherlands are positively related to the intention to settle permanently in the Netherlands (H2).

Furthermore, we investigate the effects of social ties in the origin country, and social integration in the host country. We use two indicators of social integration in the host country, namely the frequency of contact with natives (relative to frequency of contact with co-ethnics) and membership of organizations (i.e. none, co-ethnic or native). We hypothesize 
that immigrants and refugees who have relatively more social contact with natives are more likely to intend to settle permanently in the Netherlands (H3). As an indicator of social ties in the origin country, we look at whether refugees and immigrants send remittances. Remittances can be considered an appropriate measure of social ties in the origin country, because much of the remittances are sent to family and close ties in the origin country, and because recent research in the field of 'brain circulation' suggests there are important links between contacts and investment in - and return to - the country of origin (Harvey, 2012; Taylor, 1999). We hypothesize that immigrants and refugees who send remittances are less likely to intend to settle permanently in the Netherlands (H4).

Finally, we use measures of support for norms on gender equality and on the level of individual autonomy for children to assess the extent to which immigrants and refugees support these mainstream cultural values in the Dutch host society. Our last hypothesis is that immigrants and refugees who agree more with mainstream cultural values are more likely to intend to settle permanently in the Netherlands (H5).

\section{DATA AND METHODOLOGY}

Our analyses are based on the SPVA (Social Position and use of Provisions by Ethnic Minorities) survey data collected in 2003 among refugees and in 1998 and 2002 among immigrants, the SING data (Survey Integration New Groups) collected in 2009 among refugees, and the SIM data (Survey Integration Minorities) collected in 2006 among immigrants (Martens, 1999; Schothorst, 2004; The Netherlands Institute for Social Research (SCP), 2005; Hilhorst, 2007/2010). The respondents are refugees from Iran, Iraq,

Afghanistan, Somalia and the former Yugoslavia, and immigrants from Turkey, Morocco, Surinam, and the Dutch Antilles, which are the largest minority and refugee groups in the Netherlands. The respondents were selected from thirteen larger cities in the Netherlands. 
These cities were chosen because of the concentration of these groups in larger cities in the Netherlands. The respondents were randomly selected from the municipal records of the thirteen cities. About 15 per cent $(\mathrm{N}=913)$ of the immigrant respondents in the 1998 survey were re-interviewed in 2002. We have excluded these respondents from the '2002 part of the sample', so that every respondent is included only once in our analyses.

Response rates of the groups were between 30 per cent (Antilleans) and 55 per cent (Afghans). The sources of non-response showed a similar pattern across the national origin groups, the most important being that about 25 per cent of the people refused cooperation, about 15 per cent was repeatedly not at home at the time of data collection, and for about 15 per cent of the people the address was incorrect. Other sources of non-response include language difficulties, and people who were in very bad health or had passed away (Martens, 1999; Schothorst, 2004; The Netherlands Institute for Social Research (SCP), 2005; Hilhorst, 2007/2010).

From the respondents in these datasets, we have selected 'heads of household' who are first generation immigrants and who have been residing in the Netherlands for less than ten years (total $\mathrm{N}=4,344$ ). To improve the clarity of our comparison between immigrants and refugees, we have excluded respondents from the 'refugee countries' from our sample $(\mathrm{N}=174)$ who explicitly stated having economic and family motives rather than political motives for migration, and conversely also the respondents from 'immigrant countries' from our sample ( $\mathrm{N}=76)$ who explicitly stated having political motives for migration. It should be noted that these groups are so small that within-origin country comparisons of immigrants and refugees (e.g. comparing immigrants and refugees from Turkey) are not possible. For the respondents with missing values on one or more of the independent variables $(9,6 \%)$, we have used multiple imputation with the program 'ICE' in Stata 11 to impute the missing values (Royston, 2004). This method of imputation involves the creation of several datasets 
with imputed values (we use five) on which the final analyses are based (Royston, 2004). We have deleted respondents with missing values on the dependent variable $(0.5 \%)$ from the dataset. All in all, 4,024 respondents are included in our main analyses.

Although the data we use are rather unique (i.e. a large-scale survey, including detailed information on key aspects of immigrant integration), a disadvantage is the crosssectional design. Thus, our data do not rule out endogeneity problems, meaning that it is not entirely possible to test the causality of the relations between independent and dependent variables. Immigrant integration is a dynamic process in which settlement intentions can also promote immigrants' (investments in) human capital skills and social interaction with natives. Moreover, we cannot account for the selectivity in the sample that is due to selective outmigration between entry in the Netherlands and the moment of the survey.

To address this problem with the data currently available for this study, we limit our analysis to respondents who settled in the Netherlands in the last ten years prior to the survey. Furthermore, we conduct different analyses, each of these having its strengths and weaknesses. First, we run the analyses on surveys that contain all the relevant variables and with all respondents who settled in the last ten years. These surveys are SPVA 1998, 2002 and 2003, because SIM 2006 and SING 2009 surveys lack some independent variables. This first analysis is rich in detail and controls and is based on a large sample, but selective remigration within the ten year time frame is still an issue. Second, as a robustness check, we re-do the analysis among respondents who settled in the last five years. This analysis has the same level of detail and reduces the problem of sample selectivity, but does not have a big sample. Third, we re-do the analysis among respondents who settled in the last five years on all surveys, but then leaving out variables that are not included in SIM 2006 and SING 2009. This gives more cases for our robustness check, but at the potential cost of model misspecification. 


\section{Dependent Variable}

Settlement intentions were measured with the question, 'Do you intend to ever return to your country of origin?', to which respondents could answer 'yes', 'no' or 'don't know'. For our dependent variable, we contrast the respondents who do not want to return to the country of origin (but stay in the Netherlands) and those who don't know (1) with the respondents who do want to return to the origin country (0). It should be noted that the intention to settle in the Netherlands may be somewhat overestimated in this manner, because some people who indicate not having the intention to return to their origin country may have the intention to move to another (third) country.

\section{Origin Groups}

In our first hypothesis, we have divided respondents in two broad categories, immigrants and refugees, based on their self-reported motivation for migration. Because this distinction coincides with country of origin, we compare refugees from Afghanistan, Iraq, Iran, the former Yugoslavia, and Somalia to immigrants from Surinam, the (former) Dutch Antilles, Turkey and Morocco). However, because there are likely significant differences within the broad categories of immigrants and refugees, between origin country groups, we have used separate dummy variables for each of the origin countries in our main analyses; Turkey (1), Morocco (2), Surinam (3) the Dutch Antilles (4), Afghanistan (5), Iraq (6), Iran (7), the former Yugoslavia (8), and Somalia (9).

\section{Economic Integration}

We operationalise economic integration in the host country, first by looking at employment and occupational status. Respondents were asked if they were currently employed. We 
contrast respondents who are not employed (0) with respondent who are employed (1). All respondents who were employed have described their occupation. Through standardized tools, we have recoded respondents' occupation into the International Socio-Economic Index (ISEI), which is an internationally comparable measure of occupational status (Ganzeboom, et al., 1992). ISEI scores represent a continuous approach to occupational stratification and reflect a weighted sum of the average education and average income of occupational groups (Ganzeboom, et al., 1992). To illustrate, office cleaners have a score around 20, nursing personnel a score around 40, and medical doctors have a score around 85 . We use the ISEI scores, ranging from 16 to 88 , as a measure of occupational status. Unemployed respondents were given a score based on their previous occupation, and if no previous occupation was listed they were given the mean score of their respective national group. In this manner we have tried to minimize the influence of the unemployed in the effect of occupational status, while retaining as much variation in the data as possible.

In addition to employment and occupational status, we use a variable that indicates perceived financial security. Respondents were asked how often they have, over the last three months, worried about their finances. The four-point scale ranges from constantly worrying about finances to never worrying about finances.

\section{Socio-cultural Integration}

We include the composition of contacts with the Dutch majority and with members of the 'own' minority group as a measure of the relative intensity of social contact with natives. Respondents were asked to indicate if they had more native social contacts than co-ethnic, more co-ethnic contacts than natives, or an equal amount of contacts from both groups. Respondents who indicate having more native than co-ethnic social contacts (3) and those 
who indicate that they have an equal amount of native and co-ethnic contacts (2) are contrasted with those who indicate having more co-ethnic than native contacts (1).

We also include organizational membership as a measure of social contact with natives and co-ethnics. Respondents were asked if they were members of an organization and if the other members of the organization were mainly natives or co-ethnics. We include dummy variables representing respondents who are not members of an organization (1), respondents who are members of an organization with mostly co-ethnics (2) and respondents who are members of an organization with mostly natives (3). Regarding social contacts in the origin country, we use a variable for sending remittances. Respondents who do not send remittances (0) are contrasted with respondents who do send remittances (1). It has to be admitted that this is a rather indirect measurement of social contacts in the origin country, but more direct measures were unfortunately not available in our data.

Cultural integration was measured with three items on 'mainstream' cultural values, two regarding gender roles in the household; 'the household should be women's main responsibility' and 'women should stop working once they have children', and one regarding the autonomy of adult children; "children should stay in the parental home until they are married', to which respondents could answer on a five-point scale. We use the average of the three items, with a scale reliability of .59 (Cronbach's alpha), and higher scores representing more support for 'mainstream' values (more support for emancipated gender roles and autonomy for children).

\section{Demographic Controls}

We control for four compositional features of the origin groups. We include variables indicating respondents' gender, age (15-25 years, 25-45 years, and 45 or older), and years of residence in the Netherlands. Furthermore, we use a variable indicating the level of pre- 
migration education with five categories, ranging from no education at all to tertiary education.

\section{Analyses}

Because our dependent variable originally has three categories, a preliminary ordered logistic regression analysis was done first, including the 'Brant test' in STATA, which indicated that the ordered model violates the assumption of parallel regression equations (overall chi2 $=50.76, \mathrm{DF}=19, \mathrm{p}<.001)$. This means that an ordered logistic model is not appropriate for our analyses, and that binary and multinomial logistic models should be preferred. In our main analyses, therefore, we have used binary logistic regression. Moreover, we have performed additional analyses to check the robustness of our results. First, we have alternatively coded the dependent variable, including the respondents who answer 'don't know' with the respondents who want to return to the origin country (0), instead of with the respondents who want to stay in the Netherlands (1). Second, we have performed multinomial regression analyses with three separate categories on the dependent variable. The results of these robustness checks confirm the main results, and are not presented in the tables but available upon request.

\section{RESULTS}

\section{Descriptive Findings}

The descriptive statistics for the independent variables are presented in Table 1. Interestingly, Table 1 shows a number of stark differences between immigrants on the one hand and refugees on the other. Compared to immigrants, refugees tend to be higher educated prior to migration. Furthermore, refugees are more often unemployed, and perceive less financial 
security. Regarding social networks, refugees have more contact with natives and less contact with co-ethnics.

\section{[ Table 1 about here ]}

Table 2 presents descriptive statistics for the dependent variable. The intention to stay in the host country, with three categories, is shown separately for each origin country and for the two broader national origin groups. About 49 per cent of the refugees in our sample intend to stay in the Netherlands, while 33 per cent intend to return to the origin country and 18 per cent is undecided. Generally, the intention to stay in the Netherlands is lower among immigrants than among refugees. About 39 per cent of the immigrants in our sample intend to stay in the Netherlands, while 41 per cent intend to return to the origin country and 20 per cent is undecided.

However, there also appear to be important differences within the immigrant and refugee categories. Within the group of refugee countries, those who come from Somalia stand out with less than a third of respondents indicating that they intend to stay in the Netherlands. Together with the refugees from Somalia, the intention to stay in the Netherlands is lowest among the immigrants from the former Dutch colonies, Surinam and the (former) Dutch Antilles (about a third intend to stay). Among Turkish immigrants, the intention to stay in the Netherlands is somewhat lower than among refugees ( 39 per cent), but higher than among immigrants from Surinam and the (former) Dutch Antilles. Interestingly, the intention to stay in the Netherlands is about as high among Moroccan immigrants (52 per cent) as among the refugee groups.

[ Table 2 about here ] 


\section{Logistic Regression Results}

In Table 3, the results of our main analyses are presented in terms of Average Marginal Effects (AME). AME should be interpreted as the change of $\mathrm{P}(\mathrm{Y}=1)$ that is associated with a change in the predictor, from 0 to 1 in case of categorical predictors and a change of one unit in case of continuous predictors, while keeping the other predictors in the model constant. Compared to Odds Ratios (OR), considerable advantages of AME are their straightforward substantive interpretation and the possibility to compare AME across models, because they do not reflect unobserved heterogeneity as OR do (Mood, 2010).

The first model in Table 3 includes the national group dummies and control variables. The indicators of economic integration are added in the second model, and the indicators of socio-cultural integration are added in the third 'complete' model. Table 3 also shows two robustness checks, in Model 4 and Model 5. The fourth model in Table 3 shows results with a more restricted sample (i.e. having arrived in the last five years prior to the survey) $(\mathrm{N}=1,091)$. The fifth model in Table 3 shows results with additional respondents with a length of stay under five years from the 2006 and 2009 surveys $(\mathrm{N}=1,549)$, in which unfortunately not all measures were included. Below, we focus on the 'main results' that are presented in the third model of Table 3, unless mentioned otherwise.

\section{Group-level Differences}

We hypothesized that refugees would be more likely to intend to settle permanently in the Netherlands than immigrants. Table 1 already shows that the intention to settle permanently in the Netherlands is generally higher among refugees than among immigrants from Surinam, the Dutch Antilles and to a lesser extent Turkey, while there is not much difference between refugees and Moroccan immigrants. The results in Table 3 support this pattern. Using 
immigrants from Turkey as a reference group, the probability of having the intention to settle permanently in the Netherlands is about 8 percentage points higher among refugees from Afghanistan and about 16 percentage points higher among refugees from the former Yugoslavia. When compared to immigrants from Surinam and the Dutch Antilles, the intention to settle permanently in the Netherlands is higher among all refugee groups except the Somali.

The results thus support our first hypothesis, but to a limited extent, because there are important differences within the immigrant and refugee categories. In the full model, the intention to settle permanently in the Netherlands is about 15 percentage points lower among Somali refugees than among Turkish immigrants. Furthermore, Moroccans immigrants are among the groups in our study with the highest intentions to stay in the Netherlands.

[ Table 3 about here ]

\section{Individual-level Differences}

The results in Table 3 show that employment, occupational status and perceived financial security are largely unrelated to immigrants' settlement intentions. We even find a small negative relation between employment and the intention to stay in the Netherlands, though this relation is not significant in the robustness checks (Table 3, Model 4 and Model 5). We thus conclude that hypothesis 2 is not supported by the results. Regarding social integration, results show that the probability of having the intention to settle permanently in the Netherlands is indeed higher when immigrants and refugees have more native contacts (about 16 percentage points), or an equal amount of native and co-ethnic contacts (about 10 percentage points), than when they have more co-ethnic than native contacts. The results in both Model 4 and Model 5 confirm the positive association, indicating that social interaction 
with Dutch majority members is an important pull factor for immigrants and refugees early after arriving in the Netherlands. However, membership of an organization with mainly natives is not positively associated with the intention to stay in the Netherlands, when contrasted with people who are not members of an organization, and the final model even shows a significant negative association. Membership of an organization with mainly coethnics is negatively rather than positively associated with the intention to stay in the Netherlands.

We also hypothesized that immigrants and refugees who send remittances are less likely to intend to settle permanently in the Netherlands. This hypothesis is supported by the results. Sending remittances is associated with an about 3 percentage points lower probability of having the intention to settle permanently in the Netherlands. However, when we look at samples of respondents who have spent only five years or less in the Netherlands, in Model 4 and Model 5, the negative relation between sending remittances and intention to settle permanently in the Netherlands is not confirmed.

Our final hypothesis stated that immigrants and refugees who agree more with 'mainstream' cultural values (i.e. support gender equality and individual autonomy) are more likely to intend to settle permanently in the Netherlands. This hypothesis is also supported by the results. Table 3 shows that a one unit increase in support for 'mainstream' cultural values is associated with an about 3 percentage points higher probability of having the intention to settle permanently in the Netherlands.

Surprisingly, the results show that among recent immigrants and refugees, a greater length of stay in the host country is negatively associated with intentions to stay in the host country. However, this is not confirmed in the analysis of the subsample of respondents who have spent only five years or less in the Netherlands (Table 3, Model 4). Furthermore, immigrants and refugees who are older are more likely to have the intention to settle 
permanently in the Netherlands, and higher education in the origin country is negatively associated with the intention to settle permanently in the Netherlands.

Lastly, Table 3 shows that the differences in settlement intentions between the origin groups cannot be attributed to explanatory factors at the individual level. Comparing the effects of the origin dummies between Models 1, 2 and 3, we see a considerable stability of the gaps in settlement intentions between Turkish immigrants on the one hand (the reference group) and the other immigrant groups and refugee groups on the other, especially in the first three models of Table 4. Therefore, we conclude that the group differences in settlement intentions cannot be explained by compositional differences between the groups, which means that group characteristics (such as political conditions in the origin country) remain important.

\section{DISCUSSION}

In this study, we have investigated the settlement intentions of more than 4,000 immigrants and refugees in the Netherlands. We had two main questions in this study. The first question concerned how refugees and migrants differ in their settlement intentions. Secondly, we asked to what extent the intention to settle permanently in the Netherlands can be explained by economic and socio-cultural integration in the host country.

A drawback of studies on immigrants' and refugees' settlement intentions is that part of the immigrants and refugees who once held the intention to leave the host country may have left already, causing selectivity in the sample. We have addressed this drawback by analyzing a sample of recently arrived immigrants and refugees ( $<10$ years), with additional robustness checks among respondents with a maximum length of stay of five years, indicating that our results are quite robust against selection bias. 
Though immigrants generally seem less inclined to stay permanently in the Netherlands, we do not find a very clear-cut distinction between the settlement intentions of refugees on the one hand, and those of immigrants on the other. This is somewhat contrary to our expectations, considering the distinct motives for migration and the generally unfavorable political and economic conditions in refugees' countries of origin. Moreover, refugees from Somalia are even relatively unlikely to intend to settle permanently in the Netherlands. Statistics and reports on economic development and civil liberties do not suggest that conditions in Somalia are relatively favorable, however, but rather the contrary (Freedomhouse, 2009; UNDP, 2009). Because little research has been done on the settlement intentions of refugees, it remains to be investigated whether refugees from Somalia are an exceptional case only in the Netherlands, and why.

On the other hand, our study does show that immigrants from former Dutch colonies (i.e. Surinam and the Dutch Antilles), and to a lesser extent Turkey, are relatively unlikely to have the intention to settle permanently in the Netherlands. The results therefore do reflect that economic and political conditions are relatively more favorable in these origin countries, compared to the 'refugee origin countries' and Morocco, making the option of return more feasible and attractive. In a report by Freedomhouse (2009), for instance, Surinam is the only origin country in our study that receives a positive evaluation of civil liberties and political rights, while these are most limited in the refugee countries. Moreover, economic development is generally higher in Turkey and the former Dutch colonies than in the refugee countries and Morocco (UNDP, 2009). Furthermore, because individual level differences cannot explain the origin group differences, our results suggest that (a lack of) economic opportunities and political stability in the origin country can have a strong impact on the intention to stay in the host country. 
We find that economic integration in the host country is not positively related to the intention to settle permanently in the host country. This is quite surprising because economic incentives and human capital skills are important explanations of migrant settlement decisions in the literature, and a positive relation is expected from neoclassical economic theories (Constant \& Massey, 2003; Dustmann \& Weiss, 2007; Jensen \& Pedersen, 2007). Our results support arguments that the relation between economic integration and settlement intentions is more complicated. One explanation of our results is that immigrants and refugees may be disappointed about their economic opportunities in the host country. Previous studies have shown that immigrants and refugees get relatively limited returns to the educational qualifications obtained in the origin country, which leads to feelings of underemployment (Kanas \& Van Tubergen, 2009). When the quality of employment in the host country is below migrants' educational standards and their level of pre-migration employment, this may result in feelings of relative deprivation rather than integration in the host country. Future studies should therefore investigate the effects of employment in more relative terms, compared to the level of training and quality of employment in the country of origin.

Our study shows that social ties with natives and cultural integration are indeed positively related to the intention to stay in the host country. Also in line with our expectations, we find that social ties to the origin country are negatively related to the intention to stay in the host country. Our study thus to some extent confirms the argument in the recent migration literature on the role of location-specific social capital, which emphasizes the social costs of leaving the host country and the social rewards of returning to the origin country (Güngör \& Tansel, 2013; Harvey, 2009; Haug, 2008).

Contrary to our expectations, however, we find that social ties with co-ethnics are negatively associated with the intention to settle permanently in the host country. Apparently, 
co-ethnic social contacts in immigrants' social environment can also stimulate immigrants' intentions to return to the origin country. This contradicts the findings of other studies which find that contacts with both co-ethnics and natives form an incentive to stay in the host country (e.g. Haug, 2008), but is in line with research on the return intentions of Turkish students studying abroad (Güngör \& Tansel, 2008). Possible explanations for our findings are that immigrants who have the intention to return to the origin country stimulate other immigrants to return to the origin country, through transnational social ties and by promoting the sense that one is most comfortable around co-ethnics.

In sum, we find that immigrants from former Dutch colonies (i.e. Surinam and the Dutch Antilles) are less likely to have the intention to settle permanently in the Netherlands. This suggests that institutional and linguistic similarities are important group-level factors associated with return migration decisions. At the individual level, we find that social and cultural integration in the host society are positively associated with the intention to stay in the host country, among recently arrived immigrants and refugees. Our study suggests that economic motives are less important for migration decisions than is suggested in neoclassical theories of migration, but instead provides evidence for the importance of social and cultural factors. 


\section{REFERENCES}

Alberts, H., \& Hazen, H. (2005). “There are always two voices...” International Students' Intentions to Stay in the United States or Return to their Home Countries. International Migration, 43(3), 131-154.

Bijwaard, G. (2010). Immigrant Migration Dynamics Model for the Netherlands. Journal of Population Economics, 23(4), 1213-1247.

Boyd, M. (1989). Family and Personal Networks in International Migration: Recent Developments and New Agendas. International Migration Review, 23(3), 638-670.

Constant, A.F., \& Massey, D.S. (2003). Self-Selection, Earnings, and Out-Migration: A Longitudinal Study of Immigrants to Germany. Journal of Population Economics, $16(4), 631-53$.

De Haas, H., \& Fokkema, T. (2011). The Effects of Integration and Transnational Ties on International Return Migration Intentions. Demographic Research, 25(24), 755-782.

Dustmann, C., \& Weiss, Y. (2007). Return Migration: Theory and Empirical Evidence from the UK. British Journal of Industrial Relations, 45(2), 236-256.

Freedomhouse (2009). Freedom in the World 2009. Washington, DC: Freedomhouse. Report available online: http://www.freedomhouse.org/report/freedom-world/freedom-world-2009.

Ganzeboom, H.B.G., De Graaf, P.M., \& Treiman, D.J. (1992). A Standard International Socio-Economic Index of Occupational Status. Social Science Research, 21(1), 1-56.

Güngör, N.D., \& Tansel, A. (2008). Brain Drain from Turkey: An Investigation of Students' Intentions. Applied Economics, 40(22), 3069-3087.

Güngör, N.D., \& Tansel, A. (2013). Brain Drain from Turkey: Return Intentions of Skilled Migrants. International Migration, forthcoming. 
Haug, S. (2008). Migration Networks and Migration Decision-Making. Journal of Ethnic and Migration Studies, 34(4), 585-605.

Harvey, W.S. (2009). British and Indian Scientists in Boston Considering Return to their Home Countries. Population, space and place, 15(6), 493-508.

Harvey, W.S. (2012). Brain Circulation to the UK?: Knowledge and Investment Flows from Highly Skilled British Expatriates in Vancouver. Journal of Management Development, 31(2), 173-186.

Hilhorst, M. (2007). Survey Integratie Minderheden SIM 2006. Veldwerkverslag. (Survey Integration Minorities SIM 2006. Field report.) Amsterdam: Veldkamp.

Hilhorst, M. (2010). Survey Integratie Nieuwe Groepen SING 2009. Veldwerkverslag. (Survey Integration New Groups SING 2009. Field report.) Amsterdam: Veldkamp.

Jensen, P., \& Pedersen, P.J. (2007). To Stay or Not to Stay? Out-Migration of Immigrants from Denmark. International Migration, 45(5), 87-113.

Kanas, A., \& van Tubergen, F. (2009). The Impact of Origin and Host Country Schooling on the Economic Performance of Immigrants. Social Forces, 88(2), 893-915.

Leerkes, A., Galloway, M., Kromhout, M. (2011). Terug of niet? Determinanten van terugkeerintenties en -attitudes onder (bijna) uitgeprocedeerde asielmigranten. (Return or not? Determinants of return intentions and -attitudes among asylum seekers.) Mens en Maatschappij, 86(2), 122-156.

MacDonald, J.S., \& MacDonald, L.D. (1964). Chain Migration Ethnic Neighborhood Formation and Social Networks. The Milbank Memorial Fund Quarterly, 42(1), 82-97.

Martens, E. (1999). Minderheden in beeld: de SPVA 1998. (Minorities in the picture: the SPVA 1998.) Rotterdam: Instituut voor Sociologisch-Economisch Onderzoek (ISEO).

Mood, C. (2010). Logistic Regression: Why We Cannot Do What We Think We Can Do, and What We Can Do About It. European Sociological Review, 26(1), 67-82. 
Nicolaas, H., Wobma, E., \& Ooijevaar, J. (2010). Demografie van (niet-westerse) allochtonen in Nederland. (Demography of (non-Western) minorities in the Netherlands.) In R. Van der Vliet, J. Ooijevaar \& A. Boerdam (eds.), Jaarrapport Integratie 2010 (pp. 33-60). Den Haag: CBS.

Royston, P. (2004). Multiple Imputation of Missing Values. Stata Journal, 4(3), 227-241.

Schothorst, Y. (2004). SPVA-2003. Verslag van het veldwerk onder vijf groepen allochtonen. (SPVA 2003. Report on the fieldwork among five groups of minorities.) Amsterdam: Veldkamp.

Taylor, E.J. (1999). The New Economics of Labour Migration and the Role of Remittances in the Migration Process. International Migration, 37(1), 63-88.

The Netherlands Institute for Social Research (SCP) (2005). Documentation SPVA 2002. Den Haag: SCP.

UNDP (2009). Human Development Report 2009. New York: Palgrave Macmillan.

UNHCR (2007). UNHCR Statistical Yearbook 2005. Geneva: UNHCR. 
TABLE 1 Descriptive statistics for independent variables

\begin{tabular}{|c|c|c|c|c|c|}
\hline & \multirow[b]{2}{*}{ Range } & \multicolumn{2}{|c|}{$\begin{array}{c}\text { Immigrants } \\
\mathrm{N}=2,135\end{array}$} & \multicolumn{2}{|c|}{$\begin{array}{l}\text { Refugees } \\
\mathrm{N}=1,889\end{array}$} \\
\hline & & $\mathrm{M}$ & $\mathrm{SD}$ & $\mathrm{M}$ & $\mathrm{SD}$ \\
\hline \multicolumn{6}{|l|}{ Economic Integration } \\
\hline Employed & $0 / 1$ & .57 & & .35 & \\
\hline Occupational level & $16-88$ & 38.04 & 9.15 & 38.66 & 7.23 \\
\hline Financial security & $0-3$ & 1.58 & 1.04 & 1.30 & 1.07 \\
\hline \multicolumn{6}{|l|}{ Socio-Cultural } \\
\hline \multicolumn{6}{|l|}{ Integration } \\
\hline \multicolumn{6}{|l|}{ Social contacts } \\
\hline More co-ethnics & $0 / 1$ & .65 & & .42 & \\
\hline Both equally & $0 / 1$ & .24 & & .35 & \\
\hline More natives & $0 / 1$ & .11 & & .23 & \\
\hline \multicolumn{6}{|l|}{ Member organization } \\
\hline None & $0 / 1$ & .83 & & .84 & \\
\hline Co-ethnic org. & $0 / 1$ & .08 & & .02 & \\
\hline Native org. & $0 / 1$ & .09 & & .14 & \\
\hline Sends remittances & $0 / 1$ & .39 & & .29 & \\
\hline Mainstream values & $0-4$ & 1.87 & .86 & 1.80 & .85 \\
\hline \multicolumn{6}{|l|}{ Control variables } \\
\hline Male & $0 / 1$ & .58 & & .73 & \\
\hline \multicolumn{6}{|l|}{ Age } \\
\hline $15-25$ years & $0 / 1$ & .14 & & .14 & \\
\hline $25-45$ years & $0 / 1$ & .77 & & .69 & \\
\hline 45 and up & $0 / 1$ & .09 & & .17 & \\
\hline \multicolumn{6}{|l|}{ Years in the } \\
\hline Netherlands & $0-64$ & 5.90 & 3.02 & 7.70 & 1.85 \\
\hline \multicolumn{6}{|l|}{ Education in origin } \\
\hline None & $0 / 1$ & .17 & & .12 & \\
\hline Primary & $0 / 1$ & .32 & & .28 & \\
\hline Lower secondary & $0 / 1$ & .21 & & .12 & \\
\hline Higher secondary & $0 / 1$ & .23 & & .26 & \\
\hline Tertiary & $0 / 1$ & .07 & & .22 & \\
\hline
\end{tabular}


TABLE 2 Distributions dependent variable

\begin{tabular}{lcccr}
\hline & $\begin{array}{c}\text { Back to } \\
\text { origin }\end{array}$ & $\begin{array}{c}\text { Don't } \\
\text { know }\end{array}$ & $\begin{array}{c}\text { Stay in } \\
\text { NL }\end{array}$ & \multicolumn{1}{c}{$\mathrm{N}$} \\
\hline National origin group & & & & \\
Immigrants & .41 & .20 & .39 & 2,135 \\
$\quad$ Turkish & .41 & .20 & .39 & 574 \\
Moroccan & .23 & .24 & .52 & 526 \\
Surinamese & .53 & .16 & .30 & 351 \\
Antillean & .48 & .19 & .33 & 684 \\
Refugees & .33 & .18 & .49 & 1,889 \\
$\quad$ Afghan & .26 & .18 & .57 & 596 \\
Iraqi & .35 & .19 & .46 & 510 \\
Iranian & .38 & .13 & .48 & 263 \\
Yugoslavian & .18 & .26 & .56 & 212 \\
$\quad$ Somali & .51 & .17 & .32 & 308 \\
\hline Total & & & & 4,024 \\
\hline
\end{tabular}


TABLE 3 Binary logistic regression of intention to stay in the Netherlands

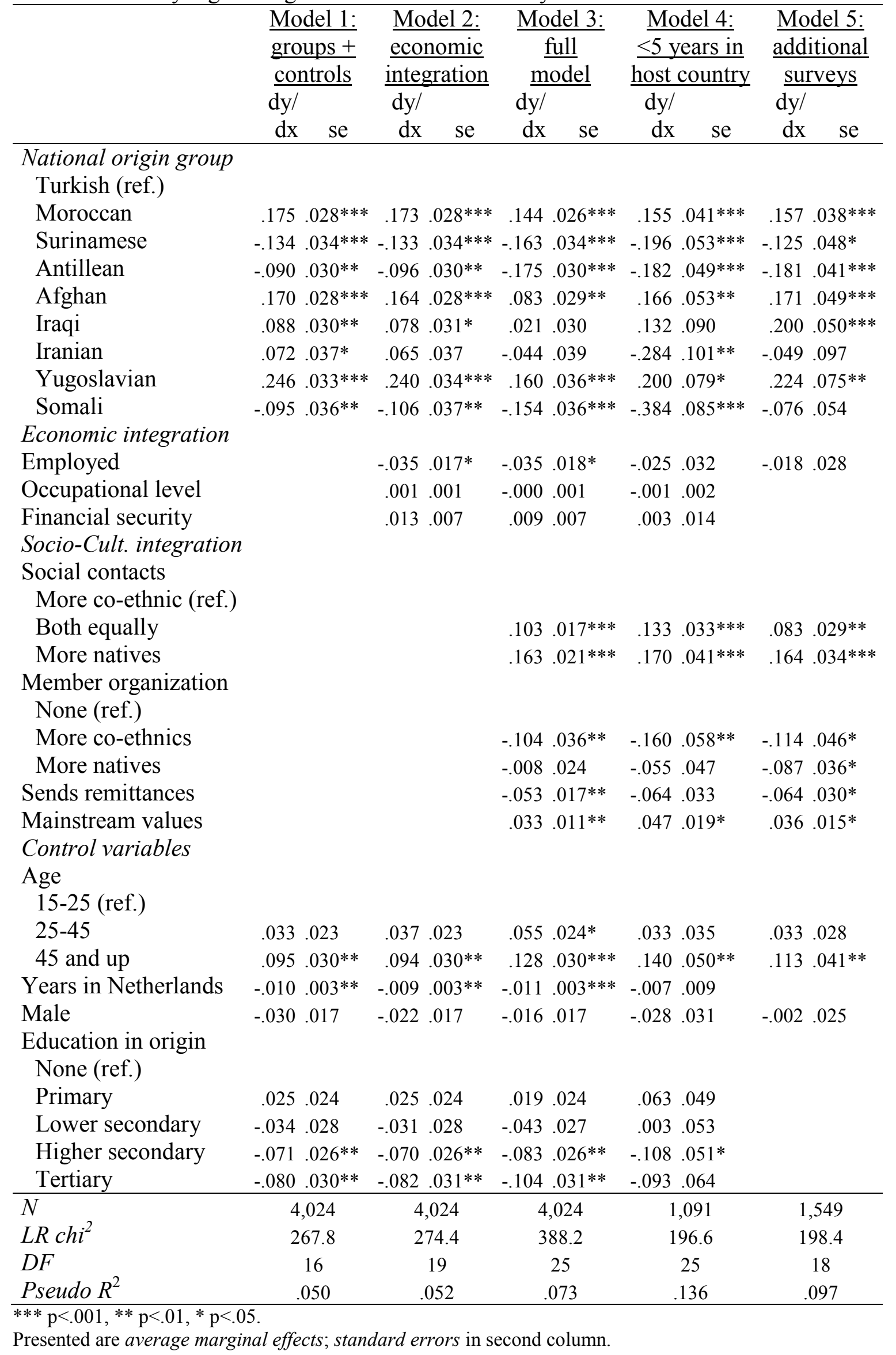

